\title{
Study on the Character Positioning of Private Universities in Shaanxi
}

\section{Province}

\author{
Guan Wang
}

Xi'an International University, Xi'an, Shaanxi, 710077

\section{Keywords: Private University, Shaanxi Province, Position Analysis}

\begin{abstract}
After more than 20 years of development, China's private higher education has become an important part of China's higher education. These developing private colleges and universities have both great opportunities and challenges in the development process. In the face of these challenges, private colleges and universities must establish the notion that the existence of higher education depends on the common demand of high-level talents, but the development of higher education depends on the irreplaceable personality, which is characteristic. So the characteristics of the positioning of private colleges and universities are essential.
\end{abstract}

\section{Introduction}

From the 1980s onwards, in the private colleges and universities have a very long period of time, the state does not have any formal laws on private education, leading to private colleges and universities to follow, long-term survival in the cracks: private colleges and universities investors dare not Bold investment, the interests of investors have been investment is not effective protection; private colleges and universities lack of norms, the quality of education is not good buckwheat. April 4, 2004, 5 private education to promote the implementation of the Act of 6 introduced the status of private higher education, the nature of some important issues given a clear, so that the development of private higher education ushered in a spring. In February 2005, the State Council issued a number of opinions on encouraging and supporting the development of private and other non-public economic development, such as monopolies, public utilities and infrastructure, social undertakings and financial services, which have long been difficult for non-public ownership Field, have access to the country's access, these will undoubtedly find opportunities to enter the private higher education private capital to open the way for the development of private higher education to provide good policy support.

\section{The Concept of Characteristic Orientation of Ordinary Undergraduate Colleges}

Characteristics must be a university is different from other universities in the school style or characteristics, there is no distinction between monotony, can not constitute a feature, so the characteristics of the first emphasis on one or more different, different characteristics of the premise.

The distinction between advantages and advantages is not in itself a characteristic, and only if this distinction is a widely recognized advantage, and this advantage reaches the extent that other universities are difficult to reach in a short period of time, it forms the characteristics of a university. Characteristics must meet the needs of social development, and its important function is to cultivate the ability to adapt to the quality of talent, that is, this feature in the process of personnel training is 
a positive effect, positive. Because the characteristics of only with the high quality, in order to get public recognition, in order to maintain a strong vitality.

The characteristics of a university are neither innate nor immutable, but a process that is a process of groping, adjusting, and developing - once the maturity is transformed into a conventional pattern and stabilized, The process of play a positive role, which is the characteristics of the characteristics of stability; development refers to the characteristics of the characteristics of the school must change with the times, update and development. Therefore, the orientation of colleges and universities is the process of inheritance and innovation. There is no inheritance, there is no foundation; no innovation, there is no university vitality and vitality, no university future and hope. The formation and development of university characteristics is the unity of inheritance and innovation of university history and culture. When we emphasize the inheritance of university history and culture, we do not exclude the absorption of modern advanced university culture. Otherwise, this university feature will become a closed rigid antique. It should be said that the characteristics of a university are both historical and modern and future. The formation and development of university characteristics, it is necessary to attach importance to the inheritance of university history and culture tradition, but also constantly blaze new trails.

\section{Problems in the Orientation of Private Higher Education in Shaanxi Province}

China's colleges and universities in the regional positioning is divided into three levels, namely the country's national key construction universities such as Peking University, Tsinghua University; provincial-level provincial universities; for the provincial government center or local university The Shaanxi Province, the private ordinary undergraduate colleges in the face of the regional positioning to show different. Xi'an Institute of Foreign Languages located in the country, the creation of the East Harvard; Xi'an Eurasia Institute in the school-oriented basic positioning for the basis of Xi'an; Xi'an Foreign Affairs Institute of the school based in Shaanxi, serving the country, look overseas; Xi'an Siyuan College orientation For the western China; Xi'an Peihua College in the school area for the positioning of the western region of China. Xi'an 's private colleges and universities in the school' s regional positioning to show a clear three - level features: facing the country, facing the province and facing the local. As a local undergraduate college in the school service area is generally for the local economic development contribution, based on the local is the correct positioning for the region, but the Shaanxi area of private colleges and universities for the regional positioning shows the positioning is too large.

Whether it is private ordinary undergraduate level of the school or specialist level of the school, according to its training objectives, is the school training into applied talents, application of talent is one of the most significant feature of the theory and practice of close integration, which requires Teaching to increase the practice of links. However, the lack of practical practice in teaching practice, private colleges and universities converge in ordinary colleges and universities undergraduate teaching, teaching tends to theoretical. However, in the survey found that most private college colleges and universities in the past in the course of running school convergence in the public undergraduate colleges and universities, especially the teaching plan emphasis on the teaching of the course ignored the practice course, the first year of teaching plan is basically a public class, Two years is the basic theory course, the third year is the professional theory course, the fourth year for the internship and find a job, but in fact the practice is basically no stable base, so the internship is only one form.

School concept, in a sense, is the school survival reasons, survival motivation, survival expectations of organic composition. From the content, including the school concept, the purpose of 
education ideas, teachers, school philosophy, from the structure, including the school objectives, work ideas, school characteristics and other factors. The function of the concept of school is to answer all the three basic questions involved in the school: why, what to do, how to do the answers to these three questions to solve the school's ultimate problem What is the school, so the school philosophy is theoretical School characteristics.

In the analysis of the school concept of the process we can find that although these private schools clearly put forward the concept of running a school, but in the philosophy of running a similar point of view that the starting point of the concept of running school students themselves, but in practice school philosophy The composition of the school not only includes the starting point of school, but also includes the goal of school development, but we in Shaanxi Province, private colleges and universities to conduct a summary of the concept of school found that they lack the vision and goals of school development, which may be their school concept defects The

Reflections on the Factors Influencing the Characteristic Orientation of Non - governmental Ordinary Undergraduate Universities in Shaanxi Province and the Countermeasures

In the course of the orientation of colleges and universities, the policy guidance of the government from the macro level to the orientation of colleges and universities is an important factor that affects the orientation of colleges and universities. As the private colleges and universities in the whole higher education system in the positioning of the rigid and development direction of the uncertainty caused by the overall characteristics of private colleges and universities difficult The At present, the current situation of the development of private higher education is that private colleges and universities can not only pursue elite academic higher education, but also very difficult to promote the popularization of higher education. From the government's policy point of view, on the one hand hope that private higher education has developed, but on the other hand also take a limited means of most of the private colleges and universities are limited to the specialist level, while requiring higher vocational education. For example, Beijing, Shanghai, Henan and other regions have announced that the field of higher vocational education should be given to private colleges and universities, but at the same time to shorten the higher vocational school system, in principle, no longer let these schools rose to undergraduate schools, private college In the level of higher vocational education; for the undergraduate level of private colleges and universities to take a one-size-fits-all approach, regardless of the development of the status quo, the trend is strictly defined in the undergraduate section, a great blow to the enthusiasm of private colleges and universities.

China's higher education classification and positioning system is mainly for public colleges and universities, this classification and positioning standards for public colleges and universities have guiding opinions. However, for the development of private colleges and universities, this positioning in the classification of government mandatory, the school conditions, the quality of running a relatively good private colleges and universities to upgrade to undergraduate schools, mainly engaged in undergraduate teaching, training and application of this type of forced private colleges and universities Into a certain level of practice, may make the development of private colleges and universities as a whole hurt. For non-profit universities, the government should not only stay in the general funding policy, but should be included in the overall planning of government education, should be the private higher education funding legal form stabilized. From the reality of China at this stage, the development bottleneck of private higher education is not the lack of private capital, and the fundamental problem lies in the lack of encouragement and attract a large number of idle funds into private higher education incentives, once the state of private higher education funding Policy stability down, then not only will guide the development of private higher 
education, but also stimulate the investment of private capital.

It is a necessary condition for the school to set up its own characteristics by changing the functions of the government and expanding the autonomy of running schools. In a highly centralized and unified school and management system, the inevitable formation of the school side, the situation of a million people, this only reform this system, so that schools have the right to determine their own school development trends, personnel training specifications And so on, the school can do their own characteristics.

The focus of the reform enrollment plan is to change the quality of students in private colleges and universities. Private colleges and universities from the date of the birth of college entrance examination students as their own enrollment object, the lack of public colleges and universities with the right to social equity enrollment, such a direct consequence of the students because of their knowledge on the basis of the lack of quality of education led to the relative Low, long-term lead to poor enrollment channels, low school level, eventually leading to the development of the school slow. To this end in the recruitment of the initial link, the Government should give a certain degree of policy tilt, in the admissions of the grade, enrollment of raw supplies to give adjustments.

\section{Conclusion}

The premise of positioning and positioning of colleges and universities is the prerequisite of positioning and positioning. Therefore, this paper attempts to analyze the characteristics of private colleges and universities from the classification standards of colleges and universities at present, and puts forward the measures to realize the breakthrough in the characteristics of private universities The It is a deficiency to test this idea from an empirical point of view, hoping that this idea will be helpful to the development of private colleges and universities.

\section{Acknowledgements}

Fund Project: Department of Education Research Project in Shaanxi. Study on the Construction and Connotative Development Strategy of Shaanxi High - level Private University.

No.: 13JZ075;

Education Department scientific research project Shaanxi: Shaanxi private colleges in the transformation of the characteristics of positioning and development strategy.

No.: 15JZ055;

\section{References}

[1] Li Mengsha. The development of private colleges in the western region [J]. Guizhou Education, $2013(03)$

[2] Min Li. The development of private colleges and universities in Shaanxi [J]. Journal of Shaanxi Normal University Journal of Continuing Education, 2004 (11)

[3] Wang Jinggui. Micro-thinking on the reform of physical education in private colleges and universities [J]. Journal of Shaanxi Normal University, 2013 (08)

[4] Lin Hefeng. Investigation and Analysis on the Present Situation of Physical Education in Art Vocational Schools in Taiyuan City [J]. Taiyuan Science and Technology, 2011 (16) 